\title{
WIETNAM
}

Nguyen Thi Thanh Thuy

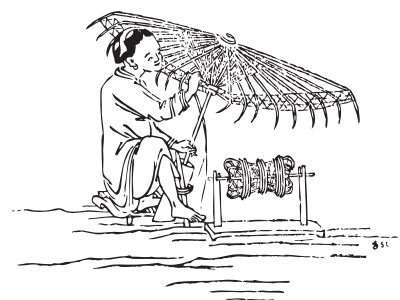

\section{Doi moi - ZMIANY SPOKECZNO-EKONOMICZNE W WIETNAMIE: ICH ŹRÓDŁA, ISTOTA I REZULTATY}

Spektakularnym sukcesem gospodarek wschodnich państw azjatyckich w ostatnich dekadach było zwiększenie dochodu narodowego na osobę i zredukowanie biedy. W ciągu ostatnich czterdziestu lat XX w. gospodarki Hongkongu, Korei Południowej, Singapuru i Tajwanu przekształciły się z biednych i zacofanych w bogate i nowoczesne, z najszybszym (jak dotąd) tempem wzrostu w historii świata. W ostatnich dekadach transformacje gospodarcze zaczęły się też w innych azjatyckich krajach, takich jak: Malezja, Tajlandia czy Chiny.

Pod koniec II wojny światowej dochód narodowy na jednego mieszkańca w Wietnamie był większy niż w Chinach i stanowił około $85 \%$ dochodu Korei, $80 \%$ - Tajlandii i Indonezji, ale tylko $62 \%$ - Filipin. Wojny, jakie Wietnam toczył od lat 50. do 70. XX w., spowodowały, iż stan jego gospodarki nie tylko nie poprawił się, ale znacznie pogorszył.

Do 1986 r. Wietnamczycy stosowali w gospodarce system centralnego planowania. Na odgórnie opracowywane plany gospodarcze niższe szczeble władzy miały niewielki wpływ, a społeczeństwo musiało zadowolić się subwencjami państwa, które zaspokajały potrzeby produkcji, konsumpcji, kultury, opieki społecznej, edukacji, sportu i innych dziedzin życia. W latach 80 . ubiegłego wieku zaczął się kryzys społeczno-ekonomiczny spowodowany gwałtownym zmniejszeniem się pomocy radzieckiej, który wraz z upływem czasu stawał się coraz bardziej dotkliwy. Zastosowane przez władze środki zapobiegawcze i mechanizmy ekonomiczne, które miały uzdrowić centralnie planowaną gospodarkę, nie przyniosły oczekiwanych rezulatów. Jedynym wyjściem z kryzysu było przejście na tory gospodarki rynkowej. Dlatego w 1986 r. VI Zjazd Komunistycznej Partii Wietnamu (KPW) 
Doi moi - zmiany społeczno-ekonomiczne w Wietnamie

zatwierdził historyczną rezolucję, która zapoczątkowała transformację gospodarki z centralnie planowanej na rynkową. Okazało się, iż wdrożone zmiany wprowadzające do życia gospodarczego mechanizmy gopspodarki rynkowej przyniosły znaczne sukcesy ekonomiczne.

\section{Proces doi moi}

\section{Dwa systemy ekonomiczne przed zjednoczeniem Wietnamu}

\subsection{Północ}

W latach 1954-1965 w Wietnamie Północnym, oficjalnie nazywanym Demokratyczną Republiką Wietnamu, wprowadzono radzieckie rozwiązania w życiu społeczno-gospodarczym. Prywatna działalność ekonomiczna była zabroniona. Po zwycięstwie nad Francuzami w 1954 r. większość średnich i dużych przedsiębiorstw została upaństwowiona. Do sektora gospodarki niepaństwowej należały jedynie zakłady rzemieślnicze i gospodarstwa rolne, które po 1957 r. zostały przekształcone w spółdzielnie produkcyjne i państwowe gospodarstwa rolne. Pierwsze stanowiły własność spółdzielczą i były zarządzane przez władze lokalne, drugie należały do państwa i podlegały władzom centralnym. Do końca lat 50 . całe rolnictwo Wietnamu Północnego zostało skolektywizowane.

W latach 1945-1976, czyli do formalnego zjednoczenia kraju, Wietnam Północny koncentrował swoją uwagę na niepodległościowej walce zbrojnej z Francją (1945-1954), Stanami Zjednoczonymi, a także z władzami Wietnamu Południowego (Republiki Wietnamu) w latach 1965-1975. Po wyzwoleniu północnej części Wietnamu z rąk Francuzów, rząd w latach 1955-1957 skupił się na reformie rolnej i kolektywizacji wsi oraz nacjonalizacji przemysłu. Radykalne zmiany społeczno-ekonomiczne w tym okresie spowodowały masową migrację ludności z Północy na Południe (objęła ona około $1 \mathrm{mln}$ ludzi) i uznane zostały później jako poważny błąd ${ }^{1}$. Niemniej jednak także zagraniczni obserwatorzy utrzymywali, że na lata 1954-1960 przypadł w Wietnamie Północnym szybki rozwój rolnictwa i przemysłu, co przyczyniło się do dynamicznego wzrostu gospodarczego ${ }^{2}$.

Ogromny wpływ na politykę wewnętrzną i zagraniczną Wietnamu Północnego w tym okresie wywierał Związek Radziecki. Nie dziwi więc, że głównym tematem III Zjazdu Partii Pracujących Wietnamu we wrześniu 1960 r. były budowa socjalizmu i walka o niepodległość kraju. Zjazd uchwalił również założenia planu

${ }^{1}$ History of the Communist Party of Vietnam, Foreign Languages Press, Hanoi 1986, s. 140. Artykuł jest dostępny na stronie internetowej: http://www.cpv.org.vn/cpv/history/index.htm.

${ }^{2}$ Melanie Beresford, Vietnam, Politics, Economics and Society, Pinter Publ., London 1988, s. 130. 
pięcioletniego na lata 1961-65, który miał skupić się na rozwoju przemysłu ciężkiego. Zagraniczni obserwatorzy podkreślali, że gospodarkę Wietnamu Północnego w latach 1959-1964 charakteryzowała „szybka industrializacja”. W latach 1960-1975 inwestycje w przemyśle rosły w tempie trzy razy szybszym niż nakłady na rolnictwo . Udział produkcji przemysłowej w dochodzie narodowym wzrósł z 18,2\% w 1960 r. do 24,2\% w 1974 r. ${ }^{4}$ Było to spowodowane głównie wzrostem pomocy zewnętrznej dla tej gałęzi gospodarki w postaci sprzętu, surowców i paliw. Państwo, promując rozwój przemysłu, postanowiło jednocześnie zmniejszyć produkcję rolną. Motorem napędowym wzrostu gospodarczego kraju stały się przedsiębiorstwa państwowe. W zarządzanie przedsiębiorstwami produkującymi towary o wysokiej jakości zostały włączone bezpośrednio władze partyjne i państwowe. Przedsiębiorstwa te otrzymały specjalne przywileje, musiały jednak kontynuować produkcję, nie zważając na koszty. Były oczywiście subsydiowane przez państwo.

W okresie wojennym głównym celem państwa było zaspokajanie wymogów sektora wojskowego. Od 1965 r. położono nacisk na branże bezpośrednio wspierające wojnę, szczególnie na budowę maszyn, produkcję żelaza, stali, węgla i elektryczności.

Podstawowym źródłem utrzymania przedsiębiorstw państwowych była pomoc zewnętrzna. W miarę upływu czasu ich zależność od pomocy zewnętrznej systematycznie powiększała się (pomoc ta wzrosła z 25\% dochodów budżetowych państwa na początku lat 60 . do prawie $70 \%$ pod koniec tej dekady). Na skutek wojny gospodarka ogromnie ucierpiała. W tym samym okresie zmniejszyła się też o $11 \%$ wydajność pracy5.

Rząd Wietnamu Północnego był całkowicie zależny od zewnętrznego finansowania, które pozwalało pokryć deficyt handlowy i budżetowy. Biurokratyczny sposób podejmowania decyzji oraz dysfunkcjonalne bodźce ekonomiczne, dotykające zarówno sektor rolny, jak i przemysłowy, doprowadziły zewnętrznych obserwatorów do konkluzji, iż w czasie zjednoczenia obu części kraju gospodarka północna zmagała się się z długotrwałym brakiem równowagi ekonomicznej. De Vylder i Fforde, autorzy wielu książek na temat doi moi, utrzymywali, iż Wietnam Północny w 1975 r. był „słabym ekonomicznie państwem”. Mimo to komunistyczne władze potrafiły zmobilizować Wietnamczyków do wyzwolenia Południa.

Ibidem, s. 132.

${ }^{4}$ Stefan de Vylder, Adam Fforde, Vietnam: an Economy in Transition, SIDA, Stockholm 1988, s. 28.

${ }^{5}$ Melanie Beresford, op.cit. 
Doi moi - zmiany społeczno-ekonomiczne w Wietnamie

\subsection{Południe}

Od lat 60. XX w. do czasu zjednoczenia Wietnamu Stany Zjednoczone miały ogromny wpływ na na strategie ekonomiczne południowej części kraju. Po 1954 r. polityka przemysłowa w Wietnamie Południowym skupiała się głównie na rozwoju rolnictwa i przemysłu lekkiego. Napływ obcej siły militarnej sprawił, że wzrosło zapotrzebowanie na żywność oraz inne towary przemysłu lekkiego, takie jak: odzież, materiały budowlane i produkty z drewna. W tym okresie dynamicznie rozwijał się również sektor usługowy. Pod koniec lat 60 . i na początku następnej dekady Stany Zjednoczone przekazały władzę nad południową częścią kraju rządowi Republiki Wietnamu. Zwiększyły również środki na inwestycje przemysłowe, a mianowicie na budowę elektrowni, na przemysł maszynowy i motoryzacyjny, usługi naprawcze oraz utrzymanie sprzętu wojskowego, zwłaszcza okrętów i samolotów. Silny wzrost ekonomiczny w tym okresie był skutkiem zewnętrznego finansowania wydatków na towary konsumpcyjne, co doprowadziło do zakłócenia równowagi pomiędzy sektorami dostarczającymi żywność dla wojsk amerykańskich a pozostałą częścią południowowietnamskiej gospodarki.

Po podpisaniu paryskiego porozumienia pokojowego w styczniu 1973 r. zewnętrzna pomoc finansowa dla Wietnamu Południowego znacznie spadła, co przyczyniło się do stagnacji ekonomicznej i zwiększenia bezrobocia, szczególnie na obszarach miejskich. Problemy socjalne, które pojawiły się w tym czasie, były związane z dyslokacją rodzin i rozszerzaniem się miejskich dzielnic biedy, które powstały w czasie szybkiej urbanizacji. Zwiększyła je w sposób znaczący duża liczba inwalidów wojennych, a także przestępczość (narkotyki i prostytucja). Znacznej dewastacji uległy też obszary wiejskie. Wskutek bombardowania oraz rozpylania substancji chemicznych zniszczone zostało środowisko nauralne i infrastruktura rolnicza, przez co radykalnie zmniejszyła się produkcja żywności ${ }^{6}$.

Zjednoczenie kraju po zwycięstwie Północy w 1975 r. jeszcze bardziej pogłębiło trudności gospodarcze Południa. Nowe władze nie wykorzystały tamtejszego potencjału ludzkiego, po części z powodu nieufności wobec środowisk biznesmenów, inteligencji, urzędników, które też nie przejawiały szczególnego entuzjazmu wobec nowego ustroju. Choć na Południu były większe możliwości ożywienia gospodarki niż na terytorium byłej Demokratycznej Republiki Wietnamu (lepiej rozwinięte sektory przemysłowy i usług, ludzie z doświadczeniem menadżerskim i jednocześnie dysponujący pewnym kapitałem), nie zostały one wykorzystane.

${ }^{6}$ Ibidem. 


\section{Sytuacja gospodarcza Wietnamu po zjednoczeniu}

Po zjednoczeniu kraju w 1976 r. integracja dwóch całkowicie różnych systemów społeczno-gospodarczych stała się ogromnym wyzwaniem. Północ i Południe miały jednak wspólną właściwość: były całkowicie zależne od zagranicznych funduszów. Po zjednoczeniu Wietnam musiał więc uporać się ze zmniejszonym dopływem dewiz, których tak potrzebował, by po wojnie odbudować i ożywić gospodarkę. Kontynuowanie przez władze polityki ekonomicznej, opierającej się na systemie nakazowym, nie przyniosło pożądanych rezultatów.

Decyzje, które zostały podjęte podczas II Plenum KC KPW w lipcu 1977 r., miały na celu kolektywizację rolnictwa na Południu? ${ }^{7}$. Postanowiono przekształcić prywatne gospodarstwa rolne w państwowe lub spółdzielcze. Władze lokalne, chcąc szybko osiągnąć zamierzony cel, siłą zmuszały rolników do tworzenia gospodarstw kolektywnych. Dążyły bowiem do powstania jak największej ich liczby, nie interesując się zbytnio, czy ich działalność zwiększy produkcję rolnąa ${ }^{8}$ Polityka subwencjonowania państwowych przedsiębiorstw (a więc i gospodarstw rolnych) bez względu na koszty ich funkcjonowania nadal obowiązywała, a nawet rozprzestrzeniła się na jego część południową. $Z$ uwagi na to, iż te rozwiązania ekonomiczne, które charakteryzowały system ówczesnej gospodarki socjalistycznej, były nieefektywne, partia po pewnym czasie uznała je za błędne.

System ten - czytamy w materiałach z II Plenum KC - byt konieczny w czasie wojny, kiedy państwo nie otrzymywało pomocy zagranicznej. Powinnien jednak zostać zlikwidowany, gdy wojna się zakończyła, kiedy kraj, teraz zjednoczony, zaczą się odradzać na bazie socjalizmu. Lecz konserwatywne pomysty i skłonność do uzależniania się od zewnętrznej pomocy opóźnity reorganizację zarzadzania gospodarka państwa. Stary system byt efektywny tylko w czasie wojny, jednak stat się przeszkoda dla całej działalności ekonomicznej9.

Nacisk na szybką budowę gospodarki socjalistycznej dał partii i rządowi mandat umożliwiający wnikanie w zarządzanie państwowymi przedsiębiorstwami i gospodarstwami rolnymi, kóre często wspomagano dotacjami pańswowymi, mimo iż przynosiły straty finansowe. Choć praktyka subwencjonowania państwowych gospodarstw rolnych prowadziła do obniżenia ich efektywności ekonomicznej, wciąż rosły publiczne środki finansowe, które w nie inwestowano, mimo iż ich udział w produkcie narodowym w latach 1976-1980 zmalał z 27,7\% do 19,7\%.

\footnotetext{
7 History of the Communist Party...

${ }^{8}$ Tri Vo Nhan, Vietnam's Economic Policy Since 1975, Institute of Southeast Asia Studies, Singapore 1990 .

${ }^{9}$ On the Eve of the Sixth Congress of the Communist Party of Vietnam, Hanoi 1986.
} 
Na północy Wietnamu proces tworzenia nowych państwowych gospodarsw rolnych i spółdzielni produkcyjnych przebiegał pomyślnie, ale ich sytuacja finansowa wciąż się pogarszała. Nie umiano nimi bowiem dobrze zarządzać, a pracujący w nich ludzie nie mieli motywacji do pracy, gdyż nie dawała im oczekiwanych korzyści. Na Południu próby przeprowadzenia kolektywizacji rolnictwa i upowszechniania idei spółdzielczości rolnej spotkały się z silnym sprzeciwem rolników, którzy zaczęli opuszczać swoją ziemię. W sezonie zimowo-wiosennym 1978-1979 około 200 tys. ha w delcie Mekongu przeznaczonych pod uprawę ryżu nie zostało zagospodarowanych. Wiele spółdzielni rolnych zostało zlikwidowanych wkrótce po ich założeniu. Plan kolektywizacji rolnictwa do 1980 r. zawiódł ${ }^{10}$. Ponadto w Wietnamie w latach 1977-1978 miały miejsce katastrofy żywiołowe. W rezultacie rząd musiał importować rekordową ilość ryżu, sięgającą 1,5 mln ton w 1979 r. ${ }^{11}$

W mieście Ho Chi Minh (dawniej Sajgon) proces upaństwowienia prywatnego handlu doprowadził do utraty pracy przez tysiące kupców. Sektory przemysłowy i komercyjny przestały się rozwijać. Dziesiątki tysięcy ludzi musiało opuścić miasto, by szukać pracy gdzie indziej. Znaczny ich odsetek stanowili tzw. hoa, czyli Wietnamczycy pochodzenia chińskiego.

Przeciętne roczne tempo wzrostu dochodu narodowego w latach 1976-1980 wynosiło $0,4 \%$, natomiast tempo wzrostu populacji osiągnęło $2,24 \%$, co oznaczało ogromny spadek dochodu na osobę. Zła sytuacja ekonomiczna skłoniła Wietnam do zmniejszenia liczebności armii, jaką dysponował po krwawej wojnie. Utrzymanie $1 \mathrm{mln}$ żołnierzy było bowiem zbyt dużym obciążeniem dla gospodarki kraju.

Społeczeństwo żyło w ubóstwie, a codzienna walka o przetrwanie stała się głównym celem obywateli. Każda osoba otrzymywała od państwa mniej niż $15 \mathrm{~kg}$ ryżu na miesiąc. Dobra konsumpcyjne, takie jak ubrania, mydło, leki oraz sprzęt i urządzenia domowe, były praktycznie niedostępne z powodu wysokich cen. W tej trudnej sytuacji wielu urzędników państwowych przyjmowało łapówki, kradło własność społeczną i przywłaszczało sobie fundusze publiczne. W rezultacie ludność zaczęła tracić wiarę w partię komunistyczną oraz w zdolność zarządzania gospodarką przez władze państwowe.

Pod wpływem powszechnego niezadowolenia zaczęto modyfikować system polityczny w kraju. W latach 1980-1982 władze dokonały zmian kadrowych: kilku starych i konserwatywnych działaczy partyjnych straciło swoje stanowiska, a ich miejsca zajęli młodsi, mniej ortodoksyjni liderzy partyjni. Objęli oni stanowiska w resortach ekonomicznych. Nie dokonano jednak wówczas żadnej istotnej zmiany w polityce ekonomicznej, ponieważ kryzys gospodarczy nie spowodował prze-

${ }^{10}$ Tran Hoang Kim, Vietnam's Economy: The Period 1945-1995 and Its Perspective by the Year 2020, Wydawnictwo Statystyczne, Hanoi 1995, s. 202.

${ }^{11}$ Wg nieoficjanych obliczeń import żywności w 1979 r. wzrosł do 2,5 mln ton. 
silenia politycznego. Wietnamscy politycy często podkreślali, że zdolność ludności do znoszenia cierpienia była wtedy ogromna. Wietnamczycy nie mieli jednak innego wyboru - ani ekonomicznego, ani politycznego. Jeśli chcieli pozostać wolnym narodem, musieli kontynuować socjalistyczną drogę rozwoju. Władze wietnamskie ówczesny kryzys społeczno-ekonomiczny tłumaczyły amerykańskim embargiem ekonomicznym.

Obserwatorzy zagraniczni utrzymywali jednak, że w Wietnamie popełniono poważne błędy podczas kolektywizacji wsi, szczególnie na południu kraju. Przywódcy wietnamscy nie docenili tamtejszej specyfiki ekonomicznej i nastrojów społecznych w tej części kraju. Kolektywizując rolnictwo, byli pewni sukcesu, tak jak na Północy. Gdyby decydenci z Hanoi mieli po 1975 r. bardziej pragmatyczne podejście do rozwoju ekonomicznego kraju, Wietnam mógłby w pełni wykorzystać zarówno polityczny entuzjazm społeczeństwa Południa, jak i całkiem nowoczesne jego doświadczenie menadżerskie, a także istniejącą tam infrastrukturę techniczną i ekonomiczną w zachodnim stylu, która miała powiązania z rynkami światowymi. W ten sposób wietnamska gospodarka mogłaby uzyskać znaczącą pozycję w Azji Południowo-Wschodniej, bez względu na embargo Stanów Zjednoczonych. Absurdalne marnowanie bogactwa w postaci ludzkiej przedsiębiorczości, koncepcja „samowystarczalności” ludności wiejskiej oraz system urzędowych zależności na modłę feudalną łączyły się z dogmatycznymi hasłami przywódców wietnamskich o wzroście sił produkcyjnych, wydajności pracy i postępie technologicznym. Spodziewano się, że system ekonomiczny, który był podobny do systemów ZSRR i Chin, odniesie wielki sukces w uzdrawianiu gospodarki nie tylko na Południu, ale również w całym kraju. Jednak tak się nie stało.

W konsekwencji kryzys społeczno-ekonomiczny w Wietnamie osiągnął apogeum w 1986 r. Wymusiło to ogłoszenie doi moi na VI Zjeździe KPW w grudniu 1986 r.

\section{Droga do doi moi i wprowadzenie reform w życie}

Przed VI Zjazdem KPW intelektualiści wątpili, czy reformy ekonomiczne w Wietnamie wejdą w ogóle w życie. Twierdzili, że gdyby odrzucony został radziecki system ekonomiczny, wówczas jedynym modelem alternatywnym byłby zachodni system gospodarki rynkowej, czyli kapitalistyczny. To z kolei wywołałoby dwa poważne niebezpieczeństwa dla rządu próbującego przeprowadzić zamianę gospodarki planowej na rynkową. Po pierwsze, wymagałoby natychmiastowej likwidacji obecnego systemu ekonomicznego, który zapewniał ludności podstawę egzystencji i socjalne bezpieczeństwo. Jego usunięcie i towarzysząca mu „terapia szokowa”, konieczna, by stłumić inflację i doprowadzić do stabilizacji makroeko- 
nomicznej, doprowadziłyby do napięć społecznych i podziału społeczeństwa na biednych i bogatych. Po drugie, wprowadzenie systemu rynkowego postawiłoby pod znakiem zapytania lub wprost podważyło prawomocność władzy partii komunistycznej, która nie przywykła dotąd do składania przed społeczeństwem sprawozdań ze swej działalności i udowadniania czynami, że ma prawo do rządzenia. Taka sytuacja wytworzyła się później we wszystkich krajach komunistycznych. Wprowadzenie systemu rynkowego prowadziło bowiem nieuchronnie do rezygnacji z jednopartyjnego systemu politycznego, do „pokojowej rewolucji”, za której pośednictwem Zachód, a zwłaszcza Stany Zjednoczone, odniosły sukces strategiczny, rozprzestrzeniając pluralizm polityczny jako model sprawowania władzy i propagując ideę społeczeństwa konsumpcyjnego ${ }^{12}$. Taka droga rozwoju gospodarczego wyraźnie kłóciła się z marksistowską koncepcją gospodarki socjalistycznej. Część polityków i ekonomistów argumentowała, że chiński model ekonomiczny byłby bardziej przydatny dla Wietnamu.

W 1986 r. kraj stanął wobec najostrzejszej fazy kryzysu gospodarczego. Pomimo kontroli cen na większość dóbr i usług roczna stopa inflacji przekraczała 700\%. Roczna wartość eksportu wynosiła około 500 mln dolarów amerykańskich, stanowiąc zaledwie połowę wartości importu (1221 mln dolarów). Prywatna działalność gospodarcza miała miejsce na małą skalę, zresztą głównie na czarnym rynku. Budżet państwa był nadwerężony z powodu wysokich wydatków wojskowych i pokrywania strat przedsiębiorstw państwowych. Nie było prawie żadnych inwestycji zagranicznych, przepaść technologiczna między Wietnamem a krajami sąsiednimi była ogromna. Poza ograniczoną liczbą dyplomatów i pracowników pomocy finansowej w Wietnamie prawie nie było zagranicznych specjalistów, w szczególności ekonomistów.

W końcu rząd w Hanoi postanowił wprowadzić reformy ekonomiczne. W Wietnamie postanowiono wykorzystać rozwiązania ekonomiczne przyjęte przez Chiny, które polegały m.in. na otwarciu gospodarki na świat zewnętrzny. Doi moi było możliwe dzięki powrotowi na scenę polityczną w lipcu 1985 r. pragmatycznego działacza z Południa Nguyen Van Linha, który był orędownikiem reform ${ }^{13}$. Odsunięty na V Zjeździe w 1982 r., po śmierci Le Duana w kwietniu 1986 r. został na VI Zjeździe KPW w grudniu 1986 r. wybrany przewodniczącym KPW. W tym samym czasie na premiera został wybrany Do Muoi, zastępując Pham Van Donga. Nguyen Van Linh był inżynierem doi moi. W artykułach publikowanych w ga-

12 Adam Fforde, Anthony Goldstone, Vietnam to 2005: Advancing on All Fronts, Economist Intelligence Unit, London 1995, s. 4.

13 Thaveeporn Vasavakul, Vietnam: Sectors, Classes, and the Transformation of a Leninist State, [w:] James W. Morley (ed.), Driven by Growth: Political Change in the Asia-Pacific Region, M.E Sharpe, New York 1999, s. 71. 
zecie partyjnej „Nhan Dan” otwarcie atakował „przestarzałe idee” partii i rządu. Zachęcał partię i obywateli do „wyzwolenia umysłu” z wszelkiego rodzaju ograniczeń, zwłaszcza w sferze gospodarczej. Nguyen Van Linh był zafascynowany Gorbaczowowskim „nowym myśleniem”. Często stawiał Gorbaczowa za przykład do naśladowania dla kadr partyjnych i państwowych. Kampania „nowego myślenia” została wprowadzona w życie po VI Zjeździe pod hasłem: „Spójrz prosto na prawdę, dokładnie oceń prawdę i objaśnij prawdę".

Reforma ekonomiczna z 1986 r. zakładała:

1. podniesienie poziomu życia obywateli;

2. uznanie mechanizmu rynkowego za kluczowy regulator gospodarczy w dalszym rozwoju Wietnamu, w ramach którego powinny ukształtować się i rozwinąć poszczególne rynki: kapitałowy, finansowy, pracy itd.;

3. przyjęcie w Wietnamie w następnych latach modelu gospodarki wielosektorowej, urealnienie działalności gospodarczej (oparcie cen w przedsiębiorstwach państwowych na rzeczywistych kosztach produkcji, ograniczenie subsydiów i kontroli cen, zwiększenie autonomii kierownictwa);

4. liberalizację życia gospodarczego (ograniczenie restrykcji wobec przedsiębiorstw prywatnych, zwiększenie zatrudnienia w prywatnych przedsiębiorstwach do 10 pracowników, eliminację monopolu państwa w handlu zagranicznym);

5. reprywatyzację;

6. poprawę stosunków międzynarodowych przez liberalizację handlu, wymianę technologii, techniki i wyników badań naukowych z zagranicą;

7. otwarcie gospodarki dla przedsiębiorstw z udziałem kapitału zagranicznego (wprowadzenie przepisów prawnych regulujących działalność przedsiębiorstw z udziałem kapitału zagranicznego, budowę stref eksportowych);

8. dewaluację donga, waluty narodowej, z 425 do 4500 za 1 USD;

9. dekolektywizację rolnictwa (zwiększenie możliwości produkcyjnych małych gospodarstw rodzinnych);

10. ograniczenie finansowania wydatków budżetowych przez druk pieniędzy;

11. podniesienie stóp procentowych (osiągnięcie dodatnich realnych stóp procentowych $)^{14}$.

W rozpoczętym po 1986 r. procesie systemowej transformacji gospodarczej można wyróżnić kilka podstawowych obszarów, na których koncentrowała się uwaga państwa i jego interwencje korygujące żywiołowe ruchy prorynkowe oraz amortyzujące ich najbardziej bolesne następstwa społeczne.

${ }^{14}$ Kazimierz Starzyk (red.), Zagraniczne inwestycje bezpośrednie w gospodarkach Azji Pacyfi$k u$, Wyd. Naukowe Semper, Warszawa 1991, s. 159. 


\subsection{Reforma w gospodarce rolnej}

Ważną część gospodarki socjalistycznej w Wietnamie stanowiło kolektywne rolnictwo. Szczególnie ważną rolę odgrywały spółdzielnie produkcyjne, które były podstawowymi jednostkami zarówno w procesie produkcji rolnej, jak i dystrybucji towarów i przetworów rolnych. Na Północy spółdzielnie produkcyjne świadczyły ponadto liczne usługi społeczne (m.in prowadziły przedszkola). Po zjednoczeniu Wietnamu próbowano ten system gospodarowania upowszechnić w całym kraju. Od 1981 r. zaczęto go jednak reformować. Pozwolono wówczas rolnikom zrzeszonym w spółdzielniach przejmować ziemię w długookresową dzierżawę, umożliwiając prowadzenie działalności gospodarczej na własny rachunek. Zagwarantowano przy tym prawo do dziedziczenia ziemi. Wskutek tego zmniejszyła się liczba spółdzielni produkcyjnych. Decyzja ta zmieniła życie znacznej części Wietnamczyków i pozytywnie wpłynęła na rozwój gospodarki rolnej w kraju.

Proces reformy rolnej był zróżnicowany regionalnie: inaczej przebiegał na północy, inaczej na południu kraju, czego powodem była odmienna organizacja kolektywnych gospodarstw rolnych. Przed reformą rolną spółdzielnie produkcyjne na północy kraju organizowały brygady i punkty pracy rolników. Praca indywidualna na własną rękę była nielegalna, choć wciąż obecna.

Na południu kraju, a szczególnie na terenach nad Mekongiem, było nieco inaczej. Miały tam miejsce dwie kolejne fale kolektywizacji: pierwsza w latach 1979-1980, jako reakcja na kryzys gospodarczy, druga natomiast od początku lat 80. do 1985 r. Spółdzielnie produkcyjne nie odgrywały tu jednak tak znaczącej roli w gospodarce wiejskiej, jak na północy kraju.

Mimo iż w północnej i centralnej części Wietnamu indywidualne gospodarstwa rolne stanowiły ważny element systemu produkcyjnego, celem polityki rolnej było wspieranie gospodarki kolektywnej. Dopiero reforma przeprowadzona w $1981 \mathrm{r}$. zwiększała autonomię indywidualnych gospodarstw rolnych, a reforma z $1988 \mathrm{r}$. ograniczała gospodarkę spółdzielczą.

Po reformie z 1988 r. spółdzielnie nadal były sponsorowane przez państwo, ale ich liczba zdecydowanie się zmniejszyła. Pozostały jednak właścicielami znacznej części gruntów wiejskich i jednym z ważnych elementów gospodarczej struktury państwa. Tylko niewielka ich część wypracowywała zyski i nie generowała strat. Niektóre ze spółdzielni otrzymywały wsparcie od rolników indywidualnych, lecz zmniejszało się ono z dnia na dzień. Dalsze reformy, przeprowadzone w 1989 r., zmniejszyły bezpośrednie zaangażowanie państwa we wprowadzanie produktów rolnych na rynek po zaniżonych cenach. Niebawem zaczęły obowiązywać ceny wolnorynkowe i udział państwa w dotowaniu żywności wyraźnie się zmniejszył.

Reformy miały duży wpływ na instytucje wiejskie. Rolnicy sami zaczęli uprawiać przekazaną im ziemię. Słaby państwowy handel lokalny musiał ustąpić przed 
konkurencją ze strony prywatnych kupców. Pod wpływem ich działalności wiele państwowych przedsiębiorstw handlowych zaczęło skuteczniej reagować na potrzeby rynku. Handel hurtowy, który wymagał dostępu do dewiz, oraz inne usługi (np. transport) nadal były jednak pod kontrolą państwa, lecz i one musiały ze sobą konkurować.

Szczególnie ważne w przeprowadzanej reformie rolnej były prawa dotyczące użytkowania gruntów rolnych. Klarowały się one przez wiele lat. Rolnicy długo nie mogli doczekać się prawnych regulacji dotyczących własności ziemi. Mimo to nastąpił wyraźny wzrost rodzinnych gospodarstw rolnych. Spółdzielcze prawo własności obowiązywało nadal w północnych i centralnych rejonach kraju, gdzie można było otrzymywać spółdzielczą ziemię na długotrwałe kontrakty. Na obszarach, gdzie spółdzielnie były słabe, ziemię i prawo do jej użytkowania otrzymywali indywidualni rolnicy z wiejskiej wspólnoty. Na południu kraju sytuacja była bardziej niestabilna i ziemia przechodziła w prywatne posiadanie nieformalnie. W miarę upływu czasu prawo użytkowania ziemi stawało się coraz bardziej przejrzyste.

\subsection{Uwolnienie cen}

Do 1989 r. ceny na wszystkie towary w Wietnamie były ustalane przez Państwową Komisję Cen. Występował również tzw. wolny rynek cen. Z jednej strony ustalone przez państwo ceny były zawsze niższe, dlatego też pojawiły się popularne powiedzenia: „Kupowanie jest jak okradanie” i „Sprzedawanie jest jak podarowanie", z drugiej zaś wolny rynek był determinowany przez podaż i popyt, dlatego też ceny na nim były dwa, trzy razy wyższe. Taka sytuacja zachęcała ludność do gromadzenia zapasów i spekulacji. Handlarze wykorzystywali tę lukę i kupowali towary po niższych państwowych cenach i sprzedawali po wyższych na wolnym rynku. Państwo ponosiło straty, ponieważ system dwucenowy prowadził do deficytu budżetowego. Dlatego też w 2. połowie 1989 r. zniesione zostało ustalanie cen przez państwo i wprowadzono swobodny obrót towarami powszechnego użytku. W związku z tym nawet ceny kontrolowane takich towarów, jak: prąd elektryczny, paliwo, cement, stal czy usługi transportowe także zbliżyły się do cen rynkowych. Reforma cenowa miała głęboki wpływ na całą sytuację gospodarczą w Wietnamie ${ }^{15}$. Mechanizm cen rynkowych i swobodny obrót towarowy zagwarantowały przedsiębiorstwom samodzielność, stymulowały produkcję i przyczyniły się do powstania równowagi między podażą i popytem. System ten eliminował subwencje państwowe, co pomogło również zredukować deficyt budżetowy.

15 Vietnam's Economic Renovation and Foreign Economic Policies, Hanoi 1995, s. 21. 


\subsection{Kurs walutowy}

W 1989 r. po przeprowadzeniu dewaluacji donga nastąpiło zrównanie kursu walut na oficjalnym i czarnym rynku. Pozwolono sektorom pozabankowym na handel złotem i walutami obcymi. Kursy donga i innych silnych walut stopniowo zaczęły być ustalane przez rynek. Ceny walut i złota w kantorach prywatnych były praktycznie związane z kursem donga wyznaczanym przez Bank Centralny i niewiele się zmieniały w późniejszych latach. Miało to pozytywny wpływ na handel zagraniczny, zwłaszcza na eksport. W marcu 1989 r. rząd wietnamski upoważnił bowiem Bank Centralny do ustalania kursów bliskich cenom rynkowym. W styczniu i lutym tego roku różnica pomiędzy ceną rynkową a państwową wynosiła kolejno 2450 i 1820 dongów w stosunku do 1 USD. Od marca do grudnia 1989 r. różnica cen pomiędzy tymi dwoma walutami wynosiła już od 250 do 530 dongów. Od 1991 r. nie wystąpiły już żadne znaczące wahania kursu. Od tamtej pory Bank Centralny ogłoszał kurs walutowy każdego dnia. System ten był również jedną z metod zwalczania szalejącej inflacji i odniósł ogromny sukces, gdyż stopa inflacji zmalała z 411\% w 1988 r. do kilku procent w 1989 r. ${ }^{16}$

\subsection{Zachęcanie do oszczędzania w systemie bankowym}

Stopa inflacji w lutym 1989 r. wynosiła 9,2\%. Rząd podwyższył oprocentowanie depozytów do $12 \%$ i ustalił oprocentowanie pożyczek dla organizacji gospodarczych na $6,5 \%$ miesięcznie (kwiecień). W tym czasie stopa inflacji wynosiła już $3,5 \%$. W następnych miesiącach, kiedy stopy procentowe obniżyły się stopniowo do $4 \%$ miesięcznie, były nadal wyższe od stopy inflacji ${ }^{17}$.

Poprzez podwyższenie oprocentowania depozytów i kredytów bankowych ponad stopę inflacji rząd wietnamski pokazał silną determinację do ustabilizowania wartości waluty narodowej. To również spowodowało zwiększenie atrakcyjności gromadzenia oszczędności w bankach, a także podniosło poziom zdolności kredytowej banków i ich udział w finansowaniu deficytu budżetowego. Zmniejszenie podaży gorącego pieniądza pomogło szybko stłumić inflację. Było to bezprecedensowe wydarzenie w historii gospodarczej Wietnamu.

Podjęte zostały także inne ważne decyzje o charakterze ekonomicznym. Uchwalone zostało prawo o przedsiębiorstwach prywatnych, zrównujące je z przedsiębiortwami sektora publicznego. Jednocześnie przeprowadzono reorganizację przesiębiorstw państwowych, dostosowując je do wymagań gospodarki rynkowej. Zostały zniesione dotacje. Przedsiębiorstwa państwowe uzyskały prawo do zmian organizacyjnych (łączenia się i dzielenia, likwidacji przez ogłoszenie upadłości itp.).

\footnotetext{
16 Ibidem, s. 22.

${ }^{17}$ Ibidem, s. 21.
} 
3.5. Reformy w handlu zagranicznym

Polityka handlowa państwa zależy przede wszystkim od jego polityki przemysłowej oraz stosunku do restrukturyzacji. Do połowy lat 80 . XX w. Wietnam naśladował radziecki model uprzemysłowienia $\mathrm{z}$ wiodącą rolą przemysłu ciężkiego. Taka struktura wymagała polityki handlowej zorientowanej do wewnątrz i kontrolowanej przez państwo, a także scentralizowanego mechanizmu regulującego i monopolu państwa w dziedzinie handlu zagranicznego.

Urynkowienie gospodarki wymaga zmiany orientacji struktur gospodarczych i polityki uprzemysłowienia. Sygnałem do przekształceń było wprowadzenie w 1988 r. trzech programów gospodarczych: produkcji żywności i artykułów spożywczych, produkcji towarów konsumpcyjnych, produkcji towarów eksportowych. Programy te były dostosowane do potrzeb gospodarki i jednocześnie jej możliwości, a także do nowego sposobu myślenia ekonomicznego, według którego eksport odgrywa ważną rolę w procesie wzrostu gospodarczego i stwarza warunki niezbędne do uprzemysłowienia w następnym okresie. Mając to na uwadze, VII Zjazd KPW wprowadził program restrukturyzacji gospodarczej, który zakładał intensywny rozwój przemysłu wydobywczego, w szczególności ropy naftowej i gazu, oraz rozwój rolnictwa i leśnictwa na potrzeby przemysłu przetwórczego, rozwój niektórych gałęzi przemysłu ciężkiego, a także infrastruktury. Wśród wielu istotnych zmian, jakie dokonały się w programie uprzemysłowienia, największe znaczenie miało jego ukierunkowanie na produkcję eksportową. Musi jej towarzyszyć produkcja takich dóbr, której kraj jest w stanie łatwo podołać. Inaczej mówiąc, Wietnam zwrócił się ku gospodarce otwartej i zorientowanej na eksport, mając na celu optymalne wykorzystanie swoich atutów w porównaniu z innymi krajami.

Najszybsze zmiany w relacjach międzynarodowych nastąpiły w ostatniej dekadzie. Gospodarka światowa w ogromnym stopniu uległa globalizacji, czemu towarzyszyły: powstanie światowej sieci produkcji, mobilności kapitału, technologii, towarów, usług i informacji. Miało to duży wpływ na międzynarodowe organizacje handlowe w każdym regionie świata i w każdym kraju z osobna. Runda Urugwajska przestała istnieć wraz z powstaniem WTO, co było krokiem ku liberalizacji światowego handlu. Cele takich organizacji, jak: NAFTA, APEC, AFTA $\mathrm{i}$ innych odzwierciedlały silny trend do regionalizacji, która także jest nieuniknionym krokiem ku globalizacji. W takiej sytuacji zarówno kraje rozwijające się, jak i rozwinięte musiały w poważnym stopniu przystosować swoją politykę handlową do nowych warunków. Wietnam i inne kraje rozwijające się, wchodząc w etap industrializacji, muszą poważnie zastanowić się nad takimi zagadnieniami, jak liberalizacja czy protekcjonizm. Wiele dotychczasowych teorii dotyczących handlu nie przystaje już do warunków obecnych i nie jest możliwe ukształtowanie przy ich pomocy nowoczesnej polityki handlowej. Analitycy, ekonomiści i poli- 
tycy muszą odpowiedzieć na następujące pytania: Jakie są względne atuty kraju? Czy należy najpierw zastępować import produkcją krajową, zanim zacznie rozwijać się eksport? Jak liberalizacja handlu może zaszkodzić krajom rozwijającym się i jak temu zapobiec?

Reformy wietnamskiej polityki handlowej, dokonane w ramach transformacji, rozpoczęły się rozluźnieniem licznych uregulowań systemowych. Pociągnęło to za sobą eliminację monopolu państwa w dziedzinie handlu zagranicznego, a następnie utworzenie instytucji typowych dla gospodarki otwartej.

Otwarcie rynku na świat nastąpiło tak gwałtownie również za sprawą sytuacji gospodarczej w Azji Południowo-Wschodniej. W tym czasie sąsiednie kraje miały bardzo wysokie tempo rozwoju handlu zagranicznego i podlegały transformacjom strukturalnym, a wyższe płace motywowały pracowników do większej wydajności w procesie wytwarzania produktów przeznaczonych na eksport. Potencjał sprzyjający rozszerzaniu handlu i inwestycji był ogromny.

W procesie liberalizacji sektora handlowego państwowe urzędy handlowe zachowały nadal swoje wpływy. Miały one dostęp do zasobów finansowych. Za ich pośrednictwem zarówno ministerstwa, jak i władze lokalne mogły kontrolować waluty obce, których wartość ustalano podczas negocjacji w rządzie centralnym. Państwowe urzędy handlowe były kontrolowane przez działające w systemie państwowej administracji jednostki gospodarcze oraz jednostki zarządzania i nadzorowania działalności handlowej. Były one kluczową częścią systemu, który umożliwiał im dostęp do taniego kredytu poprzez system bankowy i dawał możliwość czerpania korzyści gospodarczych na różne sposoby.

W dalszym procesie reform w latach 90 . ubiegłego wieku handel prywatny rozwijał się pod bokiem państwowego. Prywatne przedsiębiorstwa handlowe często współpracowały z państwowymi, które eksportując, na przykład, ryż miały specjalne przywileje, dzięki systemowi kontyngentów i umów licencyjnych.

Pomimo znaczącej liberalizacji Ministerstwo Handlu nadal zachowało ogromną władzę i kontrolowało przebieg handlu zagranicznego. Wydawało m.in. licencje na import i eksport, które pozwalały przedsiębiorstwom angażować się w handel zagraniczny. Aby przedsiębiorstwo mogło otrzymać licencję, musiało spełnić pewne wymogi, m.in. mieć kapitał minimalny, doświadczenie w handlu zagranicznym, wykwalifikowanych pracowników. W przeciwieństwie do przedsiębiorstw państwowych prywatne firmy musiały podjąć zdecydowanie więcej starań, by otrzymać licencję na ten rodzaj działalności gospodarczej.

W dodatku rząd kontynuował system kontygentów i innych środków kontroli nad importem i eksportem niektórych towarów, takich jak: ryż, tekstylia, odzież, minerały, produkty ropopochodne, nawozy, pojazdy motocyklowe, urządzenia i maszyny. Sam proces przyznawania licencji nie był jasny. 
Jeśli system działałby bardziej elastycznie, mógłby przynosić większe korzyści. Na przykład, mimo że większość kontygentów na eksport ryżu i odzieży przyznawano przedsiębiorstwom państwowym, w wielu przypadkach podstawową pracę związaną z tym eksporetm wykonanywały firmy prywatne, a przedsiębiortwa państwowe pobierały tylko opłaty za kontygent. Zwiększenie eksportu było ważnym priorytetem ekonomicznym. Dlatego podjęto starania, by zachęcić przedsiębiorstwa prywatne do uczestnictwa w handlu zagranicznym, co wydatnie zmniejszyło udział przedsiębiorstw państwowych w eksporcie.

Do 1988 r. wietnamskie przepisy handlowe utrzymały w zasadzie monopol państwa w handlu zagranicznym. Nie dziwi więc, że sprawami eksportu i importu zajmowały się wyłącznie Ministerstwo Handlu Zagranicznego i Ministerstwo ds. Stosunków Gospodarczych z Zagranicą. Ministerstwo Handlu Zagranicznego określało m.in. wielkość kwot eksportowych i importowych dla przedsiębiorstw państwowych i prywatnych. Rozluźnienie tego monopolu zapoczątkowało udzielenie wielu przedsiębiorstwom, organizacjom handlowym i prowincjom pozwolenia na bezpośrednią wymianę handlową z zagranicą. Dotychczas firmy musiały na taką działalność uzyskać licencje od rządu, limitowana była także dla nich ilość towarów przeznaczonych na eksport i import. Ograniczenia te, w połączeniu z przepisami dotyczącymi wyznaczania cen, kursu walut oraz ustalania kwot eksportowych i importowych, powodowały, że handel był z jednej strony pod ścisłą kontrolą państwa, z drugiej zaś rozwijał się wprawdzie szybko, ale chaotycznie. Działania rządu jako strony regulującej ten typ działalności gospodarczej były mało efektywne i w konsekwencji prowadziły do zniekształcenia relacji między eksportem i importem.

Rząd wietnamski kontynuował przez ostatnie lata proces uwalniania handlu zagranicznego spod kurateli państwa. Coraz większa liczba przedsiębiorstw i organizacji gospodarczych uzyskiwała pozwolenia na prowadzenie wymiany handlowej z zagranicą. Musiały się one jednak zobowiązać do przestrzegania licznych przepisów, by uzyskać licencję Ministerstwa Handlu, zgodnie z opracowaną przez nie regulacją nr 296 z 9 kwietnia 1992 r. Jednocześnie nastąpiło kontrolowane otwarcie gospodarki, głównie przez obniżenie taryfy celnej i zrównanie jej dla wszystkich podmiotów gospodarczych. Towarzyszyły temu dalsze ułatwienia dla bezpośrednich inwestorów zagranicznych na prowadzenie działalności gospodarczej w Wietnamie.

Do końca 1987 r. usunięto punkty kontrolne nadzorujące handel wewnętrzny, zwiększono autonomię przedsiębiorstw państwowych (decyzja rządu nr 217) oraz przyjęto prawo o inwestycjach zagranicznych, chcąc przyciągnąc inwestycje FDI. W kwietniu 1988 r. partia ogłosiła rezolucję nr 10: Wszechstronna odnowa zarządzania gospodarczego w rolnictwie. Rezolucja ta definiowała gospodarstwa rol- 
ne jako autonomiczne jednostki gospodarcze. Były one upoważnione do zakupu, sprzedaży oraz transferu środków produkcji na rynku, co było niedozwolone w poprzednich regulacjach prawnych. Grunty spółdzielni przekazano indywidualnym gospodarstwom chłopskim na 10-15-letnie użytkowanie, gdy zajmowały się produkcją rolną, i do 50 lat, gdy pracowały na potrzeby przemysłu. Zawierane z rolnikami kontrakty były niezmieniane przez 5 lat. Chłopi mogli korzystać z 40\% własnej produkcji. W 1988 r. funkcje banku centralnego oraz banków komercyjnych zostały rozdzielone. Wszystkie te przedsięwzięcia i zmiany ustalone na VI Zjeździe KPW utorowały drogę nowej fali radykalnych reform.

\section{Syłuacja gospodarcza Wietnamu po wdrożeniu doi moi w życie}

Proces doi moi został zainicjowany w czasie pogłębiającego się kryzysu gospodarczego w latach 80 . XX w. Rozluźniono wtedy kontrolę administracyjną nad działalnością sektora prywatnego i handlem wewnętrznym. Towarzyszyła temu poważna reforma cen i dewaluacja donga. Podejmowane przez władze próby zapewnienia równowagi rynkowej za pośrednictwem systemu monetarnego, reformy cen i płac były jednak źle skoordynowane i początkowo nieefektywne. Ogromna nierównowaga makroekonomiczna nadal utrzymywała się, a perspektywy dla gospodarki były niepewne.

\section{Punkt zwrotny: lata 1989-1992}

Punkt zwrotny w wietnamskiej gospodarce przypadł na lata 1989-1992, kiedy roczny dochód narodowy brutto wzrósł z 4,7\% (1989) do 8,1\% (1992), a inflacja spadła poniżej $20 \%$. Dlatego historia gospodarcza tego okresu jest przedmiotem naszego szczególnego zainteresowania.

Znaczna poprawa gospodarcza wystąpiła w okresie, w którym Wietnam doświadczył gwałtownego spadku pomocy finansowej z zewnątrz. Wsparcie ze strony bloku wschodniego spadło gwałtownie, ustając w latach 1990-1991, jako konsekwencja diametralnych zmian w polityce Związku Radzieckiego. Dostęp do finansów z Międzynarodowego Funduszu Monetarnego, Banku Światowego czy Azjatyckiego Banku Rozwoju był zablokowany przez Stany Zjednoczone aż do 1993 r., a tylko niektóre państwa należące do OECD udzielały Wietnamowi w tym czasie pomocy. Rząd wietnamski stanął przed trudnym wyzwaniem. Musiał bowiem w tych warunkach osiągnać stabilność cenową i walutową, pobudzając jednocześnie wzrost gospodarczy. Ówczesną politykę władz charakteryzował wyraź- 
ny kryzys w zarządzaniu gospodarką. Odpowiedzią na kłopoty ekonomiczne było wówczas pragmatyczne zespolenie liberalnej gospodarki rynkowej z ortodoksyjną makroekonomiczną stabilizacją.

W 1989 r. władze wietnamskie wprowadziły rygorystyczną politykę w stylu IMF, jednak bez pomocy ze strony tej organizacji w zmniejszeniu kosztów społecznych. Przed wprowadzeniem programu oszczędnościowego gospodarkę wietnamską dezorganizowała hiperinflacja: w 1986 r. ceny wzrosły o 774\%, w 1987 r. o $223 \%$ i w 1988 r. o $394 \%$. W tej na wpółzreformowanej gospodarce pojawiły się olbrzymie wahania cen między oficjalnym sektorem państwowym a powstającym sektorem wolnorynkowym. Zestaw środków ekonomicznych wprowadzonych w 1989 r. pomógł zredukować inflację jeszcze w tymże roku do 35\%. Początkowy sukces nie został podtrzymany z powodu niezdolności rządu do kontrolowania wzrostu podaży pieniądza $\mathrm{z}$ uwagi na słabą bazę podatkową.

W 1991 r. w wymianie handlowej z krajami rozwiązanej w połowie tego roku RWPG nastąpił poważny spadek zarówno eksportu, jak i importu. Uniknięcie spadku dochodu narodowego brutto, który w 1991 r. wzrósł o 5,8\%, wskazywało na sukces polityki rządu, chociaż nie osiągnięto jeszcze stabilizacji cenowej. Inflacja w latach 1990 i 1991 ponownie wzrosła do 67\%. Po ponownym zaostrzeniu polityki monetarnej przez rząd inflacja od 1992 r. nie przekracza 15\%.

Istotnym czynnikiem, który dynamizował gospodarkę, były wcześniejsze próby reform ekonomicznych. Kumulujące się efekty reform w sektorze rolnym, liberalizacja handlu wewnętrznego, częściowe uwolnienie cen połączone z coraz bardziej rozsądnymi warunkami wymiany walut oraz większa stabilność makroekonomiczna pobudziły podaż. W 1992 r. zarówno zyski w rolnictwie, jak i w przemyśle szybko się powiększały. Wraz ze wzrostem sprzedaży ropy naftowej spadek eksportu krajowego cofnął się i import mógł wzrosnąć. Gospodarka przetrwała kryzys z niewielką pomocą z zewnątrz.

\section{Osiągnięcie szybkiego wzrostu: lata 1993-1997}

W ciągu pierwszej połowy lat 90 . XX w. wietnamska gospodarka przebyła drogę od kryzysu gospodarczego do kwitnącego wzrostu. Sytuacja ta utrzymywała się do 1998 r., a więc do czasu, kiedy kryzys gospodarczy w Azji Wschodniej zaczą1 wywierać wpływ na Wietnam. Dochód narodowy brutto w 1992 r. wzrósł o 8\% i pozostawał na poziomie 8-9\% do 1997 r. Rosnąca podaż oraz ostrożna polityka pieniężna zapewniły od 1992 r. utrzymanie inflacji pod ścisłą kontrolą. Wzrost gospodarczy objął wszystkie sektory, także rolnictwo, które wniosło ważny wkład w jego zainicjowanie. Jakkolwiek w ujęciu statystycznym sektor przemysłowy do- 
prowadził w latach 1993-1997 do wzrostu dochodu narodowego brutto o 13-14\% rocznie, wzrost $\mathrm{w}$ rolnictwie $\mathrm{w}$ granicach $3,5-5 \%$ rocznie $\mathrm{w}$ tym samym okresie był także imponujący, jeśli zestawi się go $\mathrm{z}$ historycznym niemal regresem. Rolnictwo ciągle miało istotne znaczenie dla gospodarki (w 1994 r. wytwarzało $27 \%$ dochodu narodowego brutto), a jego ożywiony rozwój był trwałym elementem wzrostu gospodarczego. Rolnictwo zaspokajało krajowe zapotrzebowanie na żywność, której brakowało w latach 80. XX w., a także wnosiło znaczący wkład do eksportu oraz eliminowało przepaść pomiędzy dochodami w mieście i na wsi ${ }^{18}$.

W tym czasie napływ zasobów finansowych z zewnątrz nasilił się. Bezpośrednie inwestycje zagraniczne wzrosły do $832 \mathrm{mln}$ USD w 1993 r., $1048 \mathrm{mln}$ USD w 1994 r. oraz 2074 mln USD w 1997 r. W ciągu tego okresu Wietnam uczestniczył w dobrej passie wschodnioazjatyckich inwestycji. W latach 1993-1997 zewnętrzna pomoc finansowa miała jednak drugorzędne znaczenie dla rozwoju ekonomicznego kraju.

\section{3. Źródło sukcesu: przodujący eksport}

Niewątpliwą i bezpośrednią siłą napędową wzrostu gospodarczego był zwiększający się eksport. W latach 1989-1997 wartość w USD eksportowanych artykułów wietnamskich wzrosła siedmiokrotnie. Ten wysoki przyrost eksportu miał wpływ na sytuację ekonomiczną kraju. Spowodował szybki wzrost dochodu narodowego. W sektorze rolnym stopień wzrostu był większy niż zapotrzebowanie rynku żywnościowego. Szybko rosnące zyski z eksportu, uzupełniane przez napływ kapitału, stworzyły potrzebę finansowania importu przez rynek walutowy, zwłaszcza potrzebę finansowania dóbr inwestycyjnych. Uruchomienie nowych branż przemysłowych pobudziło transfer technologiczny oraz innowacje. Zyski z kwitnącej wymiany walut ułatwiły liberalizację rynku walutowego i poziomu jego zabezpieczeń.

Dobra passa w handlu zagranicznym przyczyniła się do:

- zapoczątkowania i szybkiego wzrostu eksportu ropy naftowej,

- rozwoju rolnictwa, co zapewniło zapasy żywności i w dużej mierze stymulowało wzrost eksportu,

- szybkiego wzrostu eksportu owoców morza oraz hydroponiki w latach 80 . i 90. XX w.,

- poszerzenia eksportu artykułów rolnych o kawę, herbatę, nerkowce, pieprz, cynamon, kauczuk, owoce i warzywa, szczególnie w 2. połowie lat 90. XX w.,

18 Vietnam: Selected Issues and Statistical Appendix, IMF Country Report No. 02/5, January 2002, [w:] http://www.imf.org/external/pubs/ft/scr/2002/cr0205.pdf (wejście: 27.09.2009). 
- szybkiego wzrostu eksportu odzieży i obuwia w latach 90. XX w.,

- stabilnego wzrostu eksportu produktów rzemiosła (wyroby artystyczne, ceramika, naczynia szklane, hafty) oraz wyrobów z drewna,

- upowszechnienia się sprzętu elektronicznego w miarę rosnącego eksportu (eksport wyposażenia elektronicznego spadł w 2001 r., równolegle z gwałtownym wzrostem międzynarodowego popytu na produkty elektroniczne).

Dla wzrostu gospodarczego istotne znaczenie miały geograficzne otoczenie Wietnamu i szybko rozwijające się gospodarki krajów azjatyckich, ponieważ były one głównymi rynkami zbytu dla wietnamskich artykułów eksportowych. Do krajów tych należały przede wszystkim Japonia i Chiny. Rynkami zbytu dla towarów wietnamskich były ponadto: Australia, Singapur, Stany Zjednoczone oraz Unia Europejska.

Istotną cechą tego eksportu było jego zróżnicowanie. Zapoczątkowanie sprzedaży ropy naftowej na początku lat 90 . XX w. było ważne, ponieważ pomogło wypełnić lukę na rynku walutowym, która powstała wskutek ustania pomocy zewnętrznej oraz spadku handlu z krajami RWPG. Dochód z eksportu ropy naftowej zwiększył się z 79 mln USD w 1988 r. do 756 mln USD w 1992 r. Do 1995 r. eksport ropy sięgnął 1 mld USD rocznie, co stanowiło 1/5 całkowitego dochodu z eksportu (tabela 1).

\section{Tabela 1.}

Wielkość eksportu niektórych towarów w latach 1988-2000 (w mln USD)

\begin{tabular}{|l|c|c|c|c|c|c|c|c|c|c|c|c|c|}
\hline $\begin{array}{l}\text { Wybr. } \\
\text { towary }\end{array}$ & 1988 & 1989 & 1990 & 1991 & 1992 & 1993 & 1994 & 1995 & 1996 & 1997 & 1998 & 1999 & 2000 \\
\hline $\begin{array}{l}\text { Ropa } \\
\text { naftowa }\end{array}$ & 79 & 200 & 390 & 581 & 756 & 844 & 866 & 1024 & 1346 & 1423 & 1232 & 2092 & 3503 \\
\hline Ryż & - & 317 & 272 & 225 & 300 & 363 & 425 & 496 & 855 & 870 & 1020 & 1025 & 667 \\
\hline $\begin{array}{l}\text { Prod. } \\
\text { morskie }\end{array}$ & 124 & 133 & 220 & 285 & 302 & 427 & 551 & 431 & 551 & 762 & 858 & 974 & 1479 \\
\hline Odziez & - & - & - & - & 190 & 239 & 476 & 431 & 1150 & 1503 & 1450 & 1746 & 1892 \\
\hline Obuwie & - & - & - & - & 5 & 68 & 122 & 200 & 531 & 978 & 1031 & 1387 & 1465 \\
\hline Kauczuk & 17 & 27 & 29 & 50 & 54 & 74 & 133 & 159 & 163 & 191 & 127 & 146 & 166 \\
\hline $\begin{array}{l}\text { Elektro- } \\
\text { nika }\end{array}$ & & - & - & - & - & - & - & - & - & 440 & 497 & 585 & 783 \\
\hline Razem & 733 & 1320 & 1731 & 2042 & 2475 & 2985 & 4054 & 5198 & 7337 & 9145 & 9365 & 11543 & 14449 \\
\hline
\end{tabular}

Źródło: Brian Van Arkadie, R. Mallon, Vietnam: A Transition Tiger?, ANU E Press, Canberra 2003, s. 183. 
W latach 1996-1997 sprzedaż ropy naftowej nie przestawała wzrastać, jednak zmniejszył się jej udział w całkowitym eksporcie, ponieważ zbyt produktów rolnych i wyrobów przemysłu lekkiego szybko się zwiększał. W 1999 r., mimo zwiększenia eksportu ropy, na skutek kryzysu w Azji Wschodniej spadły wpływy z handlu zagranicznego. Jednak już w następnym roku wzrost eksportu i jednocześnie cen ropy naftowej przyczynił się do zwiększenia wpływów z handlu zagranicznego o ponad $20 \%$. Obecność ropy naftowej w obrotach handlowych jest w pewnym sensie czynnikiem egzogennym, chociaż jej eksploatacja wymagała złożonych negocjacji z zagranicznymi partnerami oraz poparcia ze strony prywatnych i państwowych inwestorów. Jakkolwiek zyski z eksploatacji surowców mineralnych mogą być interpretowane jako nieoczekiwany przypływ kapitału, międzynarodowe doświadczenia pokazują, iż użytki zrobione z takich nieoczekiwanych dochodów mogą się znacznie różnić. Jest bowiem wiele przykładów, że dobra passa surowcowa wywiera nikły wpływ na podtrzymanie rozwoju lub wręcz powoduje regres - tzw. chorobę holenderską. W latach 90. XX w. Wietnam uniknął skutków choroby holenderskiej. Pomimo użyteczności dochodów z ropy naftowej wzrost jej wydobycia nie spowodował zdominowania przez ten surowiec gospodarki eksportowej kosztem innych towarów. Ich eksport zwiększał się równocześnie ze sprzedażą ropy naftowej. Przypadek ten kontrastuje z doświadczeniem nigeryjskim. Nigeria była praktycznie krajem o tym samym co Wietnam poziomie dochodu narodowego na osobę, ale szybka ekspansja dochodów z ropy naftowej wiązała się tutaj ze spadkiem konkurencyjności i poziomu tradycyjnego eksportu.

Gwałtowny wzrost produkcji ryżu, który rozwiązał problem krajowego zapotrzebowania na żywność, także wspomógł szybki rozwój Wietnamu, zapewniając mu miejsce wśród krajów należących do czołówki światowej w międzynarodowym handlu ryżem. Wietnam stał się jednym z trzech głównych eksporterów ryżu (razem ze Stanami Zjednoczonymi i z Tajlandią). W 1999 r. eksport ryżu sięgnął 4,5 mln ton. W 1. połowie lat 90. jego produkcja wzrastała o około 1 mln ton każdego roku, dzięki temu do $1996 \mathrm{r}$. ponad $3 \mathrm{mln}$ ton ryżu można było wyeksportować, co było znaczącym wkładem w cały eksport krajowy. W 2005 r. eksport ryżu wynosił $5,3 \mathrm{mln}$ ton, a w następnym - zmniejszył się do 4,5 $\mathrm{mln}$ ton $^{19}$.

Gospodarka wietnamska odnosiła sukcesy nie tylko w eksporcie ryżu, ale także innych produktów rolnych oraz owoców morza. Chociaż upadek RWPG w $1991 \mathrm{r}$. wywarł negatywny wpływ na eksport produkcji przemysłowej (gotówkowej), Wietnam zdołał szybko zdobyć rynki zbytu dla takich produktów, jak: kawa, nerkowce, kauczuk, herbata oraz, od niedawna, owoce i warzywa.

19 Vietnam Fulfils Rice Export Target for 2007, dostępny na stronie internetowej: http://english. vietnamnet.vn/biz/2007/07/721633/. 
Pomyślny rozwój eksportu rolnego był wyraźnym następstwem procesów ekonomicznych zapoczątkowanych przez doi moi. Kontynuowana polityka reform umocniła wcześniejsze bodźce ekonomiczne. Podaż żywności, hodowla, towary przemysłowe, rybołówstwo oraz produkty hydroponiki wzrastały szybko dzięki reformie cenowej i rolnej, która zmieniła świadomość ekonomiczną rolników. Pomyślnie rozwijała się też produkcja kauczuku w państwowych gospodarstwach rolnych, m.in. dzięki inwestycjom w latach 80 . XX w., coraz intensywniej wspomagana przez prywatne gospodarstwa. W eksporcie towarów takich jak nerkowce czy pieprz Wietnam stał się głównym graczem handlowym na światowych rynkach. Eksport produktów pochodzenia morskiego oraz słodkowodnego (krewetki, ryby, sepie, mątwy, kraby, raki) także szybko wzrastał, sięgając 1 mld USD w 2000 r. oraz 3,75 mld USD w $2007 \mathrm{r}$.

W latach 90. XX w. Wietnam miał szczególne osiągnięcia w produkcji kawy, wyprzedzając w jej eksporcie w 1999 r. Indonezję, dotychczas trzeciego największego producenta po Brazylii i Kolumbii, a w 2001 r. - Kolumbię. Eksport kawy wynosił wówczas ogółem 931200 ton, zaś w 2007 r. zwiększył się do 1000200 ton o wartości 1,8 mld USD ${ }^{20}$. Gdy rozpoczynał ten eksport przyjmował - jako mały producent - ceny ustalone na międzynarodowych rynkach, na których własny udział Wietnamu był drugorzędny. Musiał dostosowywać się do zmian na międzynarodowym rynku kawy, ciągle jednak mógł zwiększać produkcję bez konieczności brania pod uwagę własnego wpływu na ceny. Po upływie pewnego czasu Wietnam stał się jednak wystarczająco mocnym graczem handlowym na światowym rynku kawy, aby wywierać znaczący wpływ na światową podaż i cenę. W rezultacie korzyści ze skokowego wzrostu produkcji kawy zostały zrównoważone przez spadek jej cen na rynkach światowych do najniższych w historii. Spowodowało to spadek produkcji oraz eksportu kawy w następnych latach.

Kluczem do stabilnego sukcesu w eksporcie jest przejście na nowe produkty, kiedy udział w światowej podaży dotychczasowych wzrasta do poziomu, na którym nie można już spodziewać się zwiększenia ich sprzedaży. W Wietnamie stało się to do pewnego stopnia możliwe dzięki urozmaiceniu oferty produktów rolnych. Dalszy jednak rozwój eksportu będzie musiał opierać się na towarach przemysłowych.

Eksport przemysłowy będzie charakteryzował więc współczesny handel wietnamski. Gdy zachodnie oraz azjatyckie rynki zastąpiły na początku lat 90 . XX w. tradycyjny handel z RWPG, wzrósł eksport artykułów przemysłu lekkiego, który ukierunkował na wymagania nowych odbiorców, istniejące zakłady państwowe oraz prywatne przedsiębiorstwa, powiększające swój udział w produkcji przemy-

${ }^{20}$ Coffee Export in 2007 Surge, Earning 1,8 billion. Artykuł jest dostępny na stronie internetowej: http:/www.anhtuanplaza.com/index.php/vietnam-news/business/coffee-export-in-2007-surgeearning-1,8-billion/. 
słowej. Przykładowo - w 1996 r. eksport artykułów tekstylnych sięgnął 1 mld USD. Podobnie w 1998 r. wzrósł eksport obuwia. Zwiększenie tego eksportu było możliwe dzięki dostosowaniu się do nowych możliwości rynkowych przedsiębiorstw państwowych oraz zagranicznym inwestycjom bezpośrednim, m.in. spółkom o kapitale mieszanym, jakie tworzyły zakłady państwowe z kapitałem obcym. Wzrosło zainteresowanie sąsiednich krajów możliwościami wykorzystania taniej siły roboczej Wietnamu w tych dziedzinach produkcji eksportowej, które u nich wyparły bardziej korzystne oferty w innych branżach. Do Wietnamu przybyło wielu przedsiębiorców z regionu azjatyckiego, którzy z uwagi na korzystne warunki do produkcji przemysłowej dostarczyli surowiec, nowoczesną technologię oraz wyposażenie zakładów przemysłowych w zamian za przyszłą produkcję. Wiele z tych ekonomicznych przedsięwzięć nigdy nie pojawiło się w oficjalnych statystykach jako inwestycje zagraniczne.

Mimo silnego zróżnicowania produkcji przemysłowej oraz wzrostu eksportu przemysłowego, IMF ${ }^{21}$, wymieniając najrozmaitsze bariery ekonomiczne oraz relatywnie wysokie ceny produktów przemysłowych, oszacował system handlowy Wietnamu jako jeden z najbardziej restrykcyjnych wśród członków Funduszu w końcu lat 90. XX w. Inni zewnętrzni obserwatorzy argumentowali, że Wietnam chciał ograniczyć import, który utrudniał ochronę kapitałochłonnego przemysłu (czyli przedsiębiorstwa państwowe) oraz ograniczał handel na obszarach kraju, gdzie przynosił on największe porównawczo korzyści. Wcześniej zostało ograniczone zangażowanie $\mathrm{w}$ handel sektora prywatnego (zakaz sprzedaży produktów innych niż wytworzone przez daną firmę).

Niemniej jednak wzrost eksportu postępował nadzwyczaj szybko i poza ropą naftową dużą jego część stanowiły produkty rolne oraz przemysłu lekkiego, a więc wymagające dużego nakładu pracy ludzkiej. W ostatnich latach Wietnam odnotował przeciętny wzrost eksportu o 20\% rocznie. W 2006 r. całkowita wartość eksportu wynosiła 39,6 mld dolarów. Udział produktów przemysłowych w eksporcie wzrósł z 14\% w 1991 r. do 37\% w 1999 r. Jeśli dołączymy do tego przetworzone produkty rolne, to łącznie $\mathrm{z}$ towarami przemysłowymi stanowiły one $2 / 3$ eksportu w 1999 r. Wzrastający eksport wpłynął korzystnie na zatrudnienie, pobudził także rozwój takich gałęzi przemysłu, jak produkcja pojazdów mechanicznych i innych środków transportu, co pozwoliło wyeliminować w tej dziedzinie import. W innych natomiast gałęziach przemysłu, z uwagi na wzrost popytu krajowego na ich wyroby, import wzrósł z 56\% w 1995 r. do 61\% w 1999 r. Zamknięta dotąd gospodarka Wietnamu, o niższej wartości eksportu od dochodu narodowego brutto, przemieniła się w gospodarkę otwartą, o całkowitym obrocie handlowym większym niż roczny dochód narodowy brutto. Wymieniona tu proporcja między wartością eks-

${ }^{21}$ Vietnam: Selected Issues, Raport IMF 99/55, Washington 1999. 
portu a dochodem narodowym brutto jest w Wietnamie wyższa niż na Filipinach czy w Indonezji, podobna jak w Tajlandii, ale już znacznie niższa niż w Malezji.

\section{Sytuacja gospodarcza w Wietnamie po kryzysie finansowym w Azji}

Do ubocznych efektów integracji gospodarki wietnamskiej z gospodarką globalną należy zaliczyć jej podatność na wstrząsy zewnętrzne. Po okresie rozwoju w latach 1993-1997, napędzanego inwestycjami zagranicznymi i zwiększającym się ciągle eksportem, gospodarka wietnamska zareagowała na spadki koniunktury zarówno regionalnej, jak i globalnej. Z początkiem wschodnioazjatyckiego kryzysu gospodarczego zmalało w Wietnamie tempo wzrostu oraz gwałtownie spadły inwestycje bezpośrednie.

Gospodarka wietnamska wykazała się jednak znaczną elastycznością, mierząc się z kryzysem gospodarczym w Azji Wschodniej w 1997 r. Funkcjonowała zdecydowanie lepiej niż wiele innych gospodarek regionu (Korea Południowa, Malezja, Indonezja, Tajlandia, Filipiny i Singapur doświadczyły trwającego rok i dłużej zastoju) i lepiej niż spodziewała się większość ekonomicznych obserwatorów. Tak więc gospodarka Wietnamu przetrwała kryzys wschodnioazjatycki raczej dobrze. Dochód na osobę wciąż rósł, chociaż z mniejszą prędkością. Spadki w rozwoju światowej gospodarki w 2001 r. zaowocowały niskim wzrostem eksportu oraz niższym ogólnym wzrostem gospodarczym, niż przewidywano w długoterminowych prognozach.

Wiele czynników złożyło się na elastyczność gospodarki wietnamskiej. Pomogła zróżnicowana baza eksportowa, chociaż sam wzrost eksportu spadł poniżej 3\% w 1998 r. Eksport powrócił do dwucyfrowego współczynnika wzrostu już w latach 1999-2000. Było to rezultatem zwiększenia sprzedaży ropy naftowej oraz eksportu obuwia, odzieży i owoców morza, dzięki stworzonym wcześniej warunkom. Jedynym poważnym następstwem kryzysu wschodnioazjatyckiego w Wietnamie był ostry spadek nakładów zagranicznych, gdyż regionalni inwestorzy wcześniej odgrywali czołowe role w stopniowym wzroście zagranicznych inwestycji bezpośrednich. Po 1997 r. inwestycje te zmalały, rząd zaś jednocześnie zwolnił tempo wzrostu inwestycji państwowych. Brak kapitału został częściowo zrównoważony przez większe krajowe inwestycje prywatne, które odtąd stawały się coraz bardziej znaczące dla gospodarki. Zwiększyły się krajowe wskaźniki oszczędności i inwestycji, a napływ pomocy zagranicznej nie przestawał się akumulować, odzwierciedlając z opóźnieniem szybki wzrost zobowiązań po amerykańskim embargu z 1993 r. 


\section{Rysunek 1. Przypływ FDI do Wietnamu w latach 1988-2006}

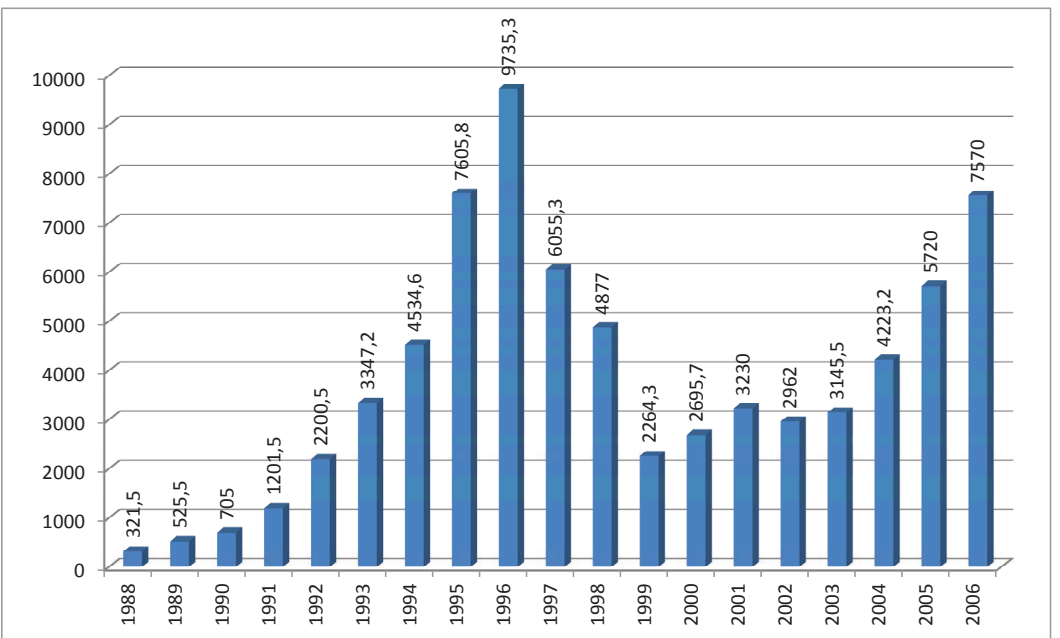

Źródło: Ministerstwo Planowania i Inwestycji Socjalistycznej Republiki Wietnamu.

Nieco ironicznie i przewrotnie można stwierdzić, że Wietnam dobrze wyszedł również na wolnym tempie reformy sektora finansowego. Zagraniczne banki mogły otwierać nowe oddziały, gdyż krajowy rynek kapitałowy był dopiero we wczesnym stadium rozwoju. Większość międzynarodowych wpływów dewizowych służyła sfinansowaniu zagranicznych inwestycji bezpośrednich. Portfel inwestycji czy przepływów z zewnątrz do krajowego systemu bankowego lub lokalnych rynków finansowych był niewielki. Chociaż przed 1998 r. wystąpiło pewne ożywienie, szczególnie w dziedzinie inwestycji zagranicznych w sektorze nieruchomości, nie było jednak żadnego boomu finansowego napędzanego przez wpływy z zagranicy czy ekspansję kredytów bankowych, czego doświadczyły inne kraje w regionie. Spowolnienie w międzynarodowej koniunkturze nie spowodowało zmniejszenia tempa reformy gospodarczej w Wietnamie. Wydaje się, że zmniejszenie tempa wzrostu inwestycji zagranicznych było uwarunkowane zwróceniem większej uwagi przez państwo na rozwój krajowego prywatnego sektora gospodarczego

Reforma systemowa w Wietnamie odniosła sukces, przynosząc w latach 90. XX w. wysoki wzrost niemal we wszystkich sektorach gospodarki i prowincjach kraju. Średnioroczny wskaźnik wzrostu PKB wynosił wówczas 7\%, a w latach 2001-2005-7,5\%. W przeliczeniu na 1 mieszkańca w 2005 r. PKB było dwukrotnością wartości z 1996 r. i wynosiło 600 USD na osobę ${ }^{22}$.

22 Do Duc Minh, Tai Chinh Viet Nam 2001-2010, Hanoi 2005. 


\section{Rysunek 2. Tempo wzrostu PKB w latach 1977-1985 (w \%)}

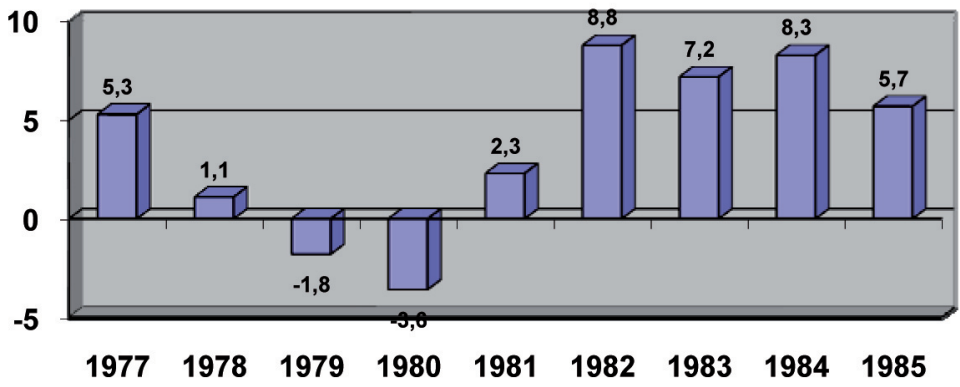

\section{Rysunek 3. Tempo wzrostu PKB w latach 1986-1995 (w \%)}

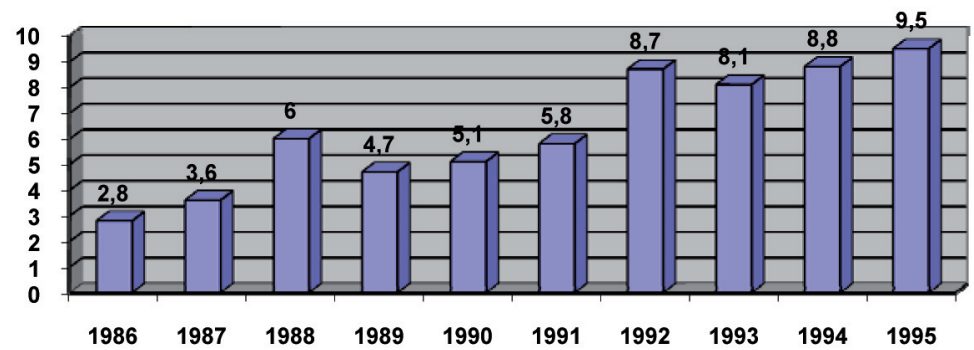

\section{Rysunek 4. Tempo wzrostu PKB w latach 1996-2006 (w \%)}

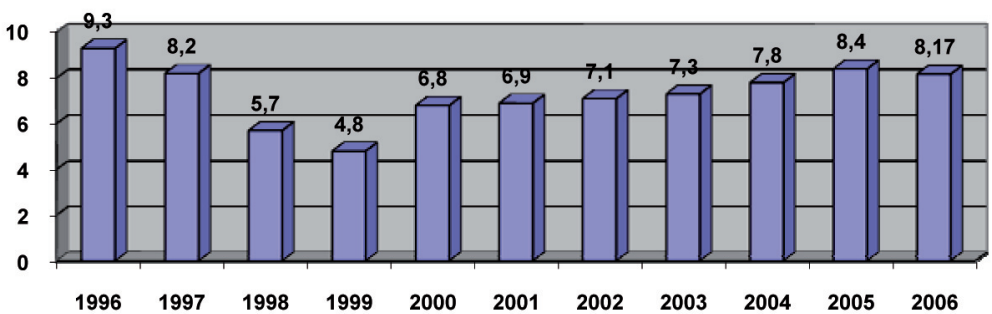

Źródło: Vietnam Economic Times, „Kinh Te 2005-2006”, s. 6.

Poprawa sytuacji gospodarczej doprowadziła do redukcji stopy ubóstwa w Wietnamie. Wskaźnik ten był w 2005 r. dwukrotnie niższy w porównaniu z 2000 r. i spadł odpowiednio z $33 \%$ do $22 \%$. Korzystnie zmieniła się struktura gospodarki: sektor przemysłowy i budowlany wzrósł z 36,7\% w 2000 r. do 42\% w 2005 r., sektor rolniczy zmalał z 24,5\% w 2000 r. do 19\% w 2005 r., sektor usług stanowił zaś ponad $38 \%{ }^{23}$.

Produkcja przemysłowa utrzymywała wysokie tempo wzrostu gospodarczego, zwiększając się przeciętnie o 15,7\% rocznie (wskaźnik ten jest wyższy o 2,7\% w po-

${ }^{23}$ Do Duc Minh, op.cit., s. 37. 
równaniu z planowaną stopą wzrostu i wyższy o 1,6\% w porównaniu z 2000 r.). Produkcja sektora państwowego wzrosła o $12,1 \%$ w porównaniu z planowanym 9,5\%, sektora prywatnego zwiększyła się o $21,8 \%$, a sektora FDI o 15,3\%.

Wartość produkcji sektora usługowego wzrastała rocznie o ok. 7,0\%. Jest to jedyny sektor, który miał takie tempo wzrostu gospodarczego, jakie planowano.

\section{Rysunek 5. Udział poszczególnych sektorów w gospodarce narodowej (w \%)}

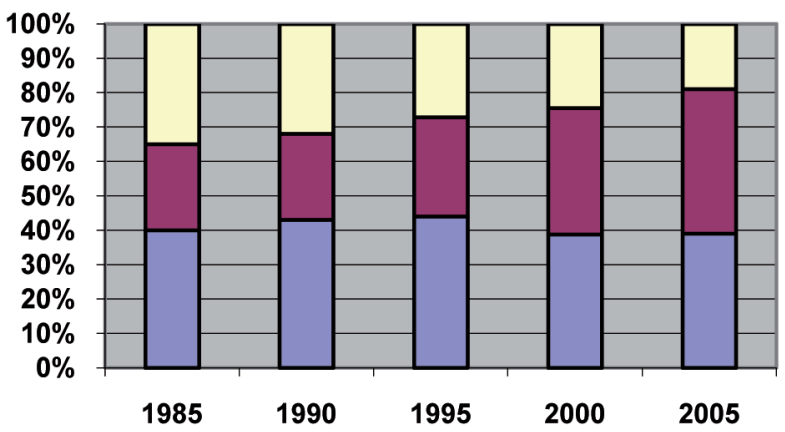

口Sektor rolnictwa
aSektor przemysłu
口Sektor usługi

Źródło: Dane te zostały zgromadzone przez autorkę z różnych źródeł, m.in. z roczników statystycznych oraz raportów Banku Światowego.

Powyższy rysunek przedstawia także zmiany w strukturze gospodarki wietnamskiej w ostatnich latach. Pokazuje m.in., że udział sektora przemysłowego w PKB zmniejszył się z 28,9\% w 1986 r. do 22,7\% w okresie kryzysu na początku lat 90. XX w. oraz zwiększył do 28,8\% w 1995 r. Obecnie (2007) udział ten wynosi ponad $40 \%$.

\section{Tabela 2.}

\section{Stopy wzrostu PKB w poszczególnych sektorach gospodarczych (w \%)}

\begin{tabular}{|l|c|c|c|c|c|c|}
\hline & 2000 & 2001 & 2002 & 2003 & 2004 & 2005 \\
\hline PKB & 6,7 & 6,8 & 7,0 & 7,3 & 7,6 & 8,4 \\
\hline $\begin{array}{l}\text { Rolnictwo, Leśnictwo, } \\
\text { Rybotówstwo }\end{array}$ & 4,0 & 2,7 & 4,1 & 3,6 & 3,5 & 4,0 \\
\hline Przemyst i budownictwo & 10,1 & 10,4 & 9,4 & 10,4 & 10,2 & 10,6 \\
\hline Usługi & 5,6 & 6,1 & 6,5 & 6,4 & 7,4 & 7,5 \\
\hline
\end{tabular}

Źródło: Urząd Statystyczny Socjalistycznej Republiki Wietnamu.

Wietnam stara się zintegrować swoją gospodarkę z rynkami światowymi poprzez podpisanie dwustronnego porozumienia handlowego ze Stanami Zjedno- 
czonymi w 2001 r., członkostwo w ASEAN oraz wstąpienie do WTO w styczniu 2007 r. To potwierdza jego zobowiązanie do otwarcia się na świat zewnętrzny oraz do integracji z międzynarodową społecznością, jak również wolę zaakceptowania międzynarodowych zasad gry rynkowej w celu wzmocnienia wietnamskiej pozycji w światowej wspólnocie gospodarczej i handlowej oraz wiarygodności wobec inwestorów krajowych i zagranicznych.

W 2006 r., aby polepszyć środowisko inwestycyjne, parlament Wietnamu uchwalił prawo o inwestycjach i prawo o przedsiębiorstwach.

\section{Podsumowanie}

Reformy ekonomiczne w Wietnamie przeprowadzano stopniowo. W ten sposób uniknięto kryzysu i załamania gospodarczego oraz przekonano do reform i zdobyto dla nich poparcie społeczeństwa, zanim jeszcze zmiany zaowocowały pozytywnymi rezultatami. Ocena reform ekonomicznych w Wietnamie nie będzie zrozumiała, jeśli nie uświadomimy sobie roli pełnionej w procesie transformacji przez instytucje gospodarcze. Stopniowe reformowanie gospodarki miało istotne znaczenie do 1989 r. Następnie zaczęto w niej wprowadzać radykalne zmiany. Wymogła je niestabilna sytuacja makroekonomiczna oraz ustanie pomocy finansowej z krajów należących do byłego bloku socjalistycznego. Przeprowadzone w latach 90. XX w. reformy gospodarcze zakończyły się sukcesem. Dzięki nim stworzone zostały mocne podwaliny dla współczesnej gospodarki Wietnamu, która przeszła transformację z gospodarki państwowej, centralnie planowanej i opartej na dotacjach budżetowych, w gospodarkę rynkową.

Osiągnięcia społeczno-ekonomiczne Wietnamu wiążą się z:

1. uznaniem prawa do działalności gospodarczej osób i firm prywatnych oraz z przeprowadzonymi reformami rynkowymi;

2. otwarciem się na świat (wyrażającym się głównie w kontaktach handlowych i bezpośrednich inwestycjach zagranicznych), integracją gospodarki krajowej z gospodarką światową i regionalną;

3. utrzymywaniem stabilizacji makroekonomicznej oraz społeczno-politycznej.

Cele rozwoju gospodarczego Wietnamu na lata 2001-2020 są ambitne. Zakłada się m.in. przyspieszenie procesu industrializacji i modernizacji jego gospodarki w celu likwidacji zacofania ekonomicznego, aby w 2020 r. stał się krajem przemysłowym. Wietnam spodziewa się wysokiego wzrostu ekonomicznego wraz ze skuteczną redukcją ubóstwa. Obecnie stawia czoło ogromnym wyzwaniom. Będąc krajem o niskim dochodzie narodowym, stara się w okresie przejściowym zmodernizować i rozwinąć swoją gospodarkę, by dorównać gospodarkom w regionie. Kie- 
dy zaczęto odnotowywać poważne osiągnięcia socjoekonomiczne, wystąpił brak równowagi ekonomicznej. Ostatnio uzewnętrzniły się słabości w sektorze przedsiębiorstw państwowych, systemie finansowym, inwestycjach publicznych, edukacji i systemie szkolenia pracowników. Może to doprowadzić do braku stabilizacji gospodarczej oraz do zwolnienia lub utraty szybkiego tempa rozwoju ekonomicznego. Ponieważ sytuacja zewnętrzna zmieniła się znacząco z uwagi na integrację regionu, międzypaństwowe porozumienia gospodarcze, rosnącą pozycję Chin na arenie międzynarodowej, Wietnam może odnieść znaczące korzyści z międzynarodowej integracji ekonomicznej i z liberalizacji handlu. Jednak współczesne zagrożenia, jak: degradacja środowiska naturalnego, epidemia AIDS czy terroryzm, mogą pogorszyć sytuację ekonomiczną w Wietnamie, jeśli jego gospodarka będzie zbyt szybko integrować się z gospodarką światową i regionalną. Koszty dostosowania się w procesie integracji mogą być znaczne. Rodzi się więc pytanie, czy Wietnam podejmie bardziej aktywne i efektywne działania ekonomiczne w odpowiedzi na współczesne wyzwania? Obecnie w procesie przeprowadzania reform Wietnam musi zmierzyć się z następującymi skomplikowanymi i trudnymi zagadnieniami:

- Spójność reform z procesem międzynarodowej integracji; trzeba przy tym pamiętać, że proces reform gospodarczych w kraju jest uzależniony od realizacji międzynarodowych zobowiązań.

- Zmiana sposobu myślenia o gospodarce; dawne nawyki związane z gospodarką państwową, centralnie planowaną, wywierają nadal znaczący wpływ na aktualną politykę ekonomiczną.

- Ponowne rozważenie założenia, że reformy gospodarcze powinny być wprowadzane stopniowo; nie jest już ono odpowiednie z uwagi na globalizację procesów gospodarczych, międzynarodową integrację oraz rozwój nowych technologii produkcyjnych; inną słabością tego założenia jest zasada stop-and-go, która jest niezgodna z obrotem biznesowym, z nieprzewidzianą inwestycją i z działalnością środowiska biznesowego; zasada ta może spowodować też konflikty między władzą centralną a władzami lokalnymi.

W rezolucji IX Zjazdu KPW (styczeń 2004) zapowiedziano przyspieszenie reform gospodarczych. Władze partyjno-państwowe zobowiązały się m.in. do:

- kontynuowania reform w sektorze przedsiębiorstw państwowych i przyspieszenia prywatyzacji tych przedsiębiorstw, stymulowania rozwoju przedsiębiorstw prywatnych i spółdzielni, zwiększenia konkurencyjności przedsiębiorstw państwowych i efektywności inwestycji pochodzących z budżetu państwa, a także zwiększenia udziału w rozwoju gospodarczym inwestycji zagranicznych;

- wzmocnienia i równoległego rozwoju takich krajowych czynników produkcyjnych, jak: kapitał, siła robocza i ziemia; 
- przeprowadzenia zmian w strategiach rozwoju socjoekonomicznego i dostosowania ich do struktury ekonomicznej kraju;

- tworzenia nowych miejsc pracy i redukcji ubóstwa;

- zmiany funkcji państwa w rozwoju ekonomicznym kraju, reform administracyjnych i zmian w ustawodawstwie gospodarczym oraz wzmocnienia demokracji w zarządzaniu gospodarką.

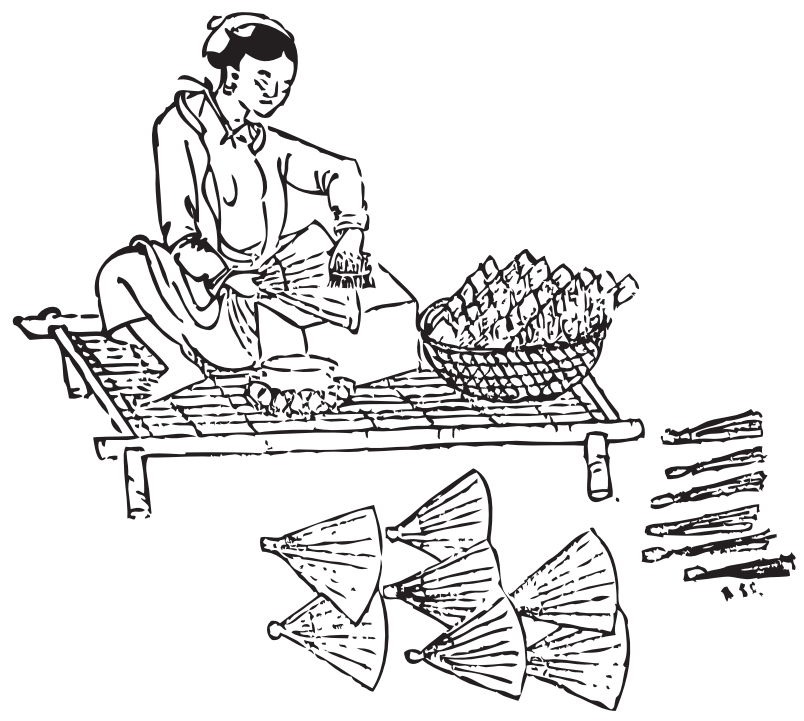

